\title{
Can change damage your mental health?
}

\section{The US Court of Appeals says that environmental impact statements should cover psychological factors, giving environmental pressure groups a licence for mayhem.}

The United States Appeals Court in Washington has put a pistol, perhaps even a bazooka, into the hands of opponents of new developments of any kind. The court has now ruled (see page 179) that electricity cannot be generated at the undamaged reactor at the Three Mile Island site on the Susquehanna River in Pennsylvania until its luckless owner has shown that the mental health of the local population will not as a result be damaged. The decision is important not merely because it may be the straw that breaks the back of Metropolitan Edison but because it can in principle apply to any project caught by the Natural Environmental Policy Act, 1970.

So far, impact statements have been attempts to anticipate physical, biological and social consequences of new developments. In many ways, they have been interesting and even important documents. The impact statement on the Alaskan pipeline may even now be the handiest source of information on the migration of caribou, for example.

Impact statements as they are suffer from a common imbalance. The most tangible and easily anticipated consequences of some new development are covered in great detail. The species of flora and fauna within striking distance of a development site are usually catalogued in detail, as are the volumes of traffic expected on the highway system. (Farseeing developers do their best to recruit the help of the local university in carrying out this kind of work.) The less tangible but usually more important issues raised by new development projects are, perhaps inevitably, given less close attention. While it may be possible to estimate the long-term consequences of a new development for the economic development of a neighbourhood, even that kind of calculation is necessarily shot through with sources of error. And so far, those responsible for preparing impact statements - itself a kind of growth industry - have shrunk from trying to estimate whether a development will make the local population happier. The importance of last week's decision is that it requires not merely the owners of the Three Mile Island nuclear site, but in principle all other managers of public works in the United States, to show that their proposals will not bring psychological damage.

The objective is laudable but the task which it implies is both impossible and, on grounds of principle, irrelevant. What has happened around Three Mile Island since the accident in March 1979 should have given the Appeals Court pause. The population in the neighbourhood of the reactor has understandably been a focus of interest for social scientists seeking evidence of the minor psychological consequences of such an occurrence. Most accounts of these investigations appear to agree that during the immediate crisis, people living within fifteen miles or so of the damaged reactor consumed more sleeping pills than those living further off. Some of these habits persisted for as much as nine months, but Dr Peter Houts of Pennsylvania State University, the author of one of the most through investigations of this kind, says that his latest survey, in October last year, shows no residual measurable consequences of the reactor accident. Other studies, reported by the Kemeny Commission, suggest that at no stage were the signs of stress reported by the local population sufficient in frequency and intensity to qualify as psychiatric illness.

Against this background, it is inconceivable that environmental impact statements purporting to describe the psychological impact of some new project can be more than fanciful fiction. It is just conceivable that, as at Three Mile Island, it might be possible to measure something tangible. But how, in the absence of a range of studies in the neighbourhood of sites capable of generating serious accidents will it be possible to predict the psychological stress caused by some new development? Will the federal government be expected now to sponsor essential baseline investigations of the incidence of minor symptoms of anxiety among people living near, say, Titan missile silos, or projected missile sites as well as nuclear reactors? What is the chance that the results will be statistically significant? And what use will they be to the drafters of future environmental impact statements?

Even if the measurements the court supposes could be made were made, however, they would be irrelevant. Provided that development projects are not so awesome that they topple people over into frank psychiatric illness, the all-important question becomes that of whether there should be a moratorium on all development projects likely to increase the general level of anxiety in the population. Presumably hydroelectric schemes of all kinds would quickly be stopped, however necessary their output of energy. So too would most defence projects and all nuclear projects. The result would be a nonsense, so that the court's decision must be changed. But that will take time. Meanwhile, environmentalists have a licence to do irreparable damage.

\section{Paying the price for coal}

\section{The British coal industry, again in crisis, should} be either closed or administered logically.

In February 1974, the then Conservative government called a general election in the wake of a damaging strike about pay by British coal miners. The central issue at the election was the government's question "Who governs Britain?" - the elected government or the miners. The rhetorical question was never answered, although $\mathrm{Mr}$ Edward Heath, prime minister at the time, was clearly told that it should not thereafter be him. A similar tangle with workers in nationalized industries among whom the coal miners were again conspicuous put paid to the government which succeeded his, in the spring of 1979 , and paved the way for the present administration. It is therefore inevitable that Mrs Thatcher and her colleagues should be nervous about the outcome this week of the ballot among the miners, who are being

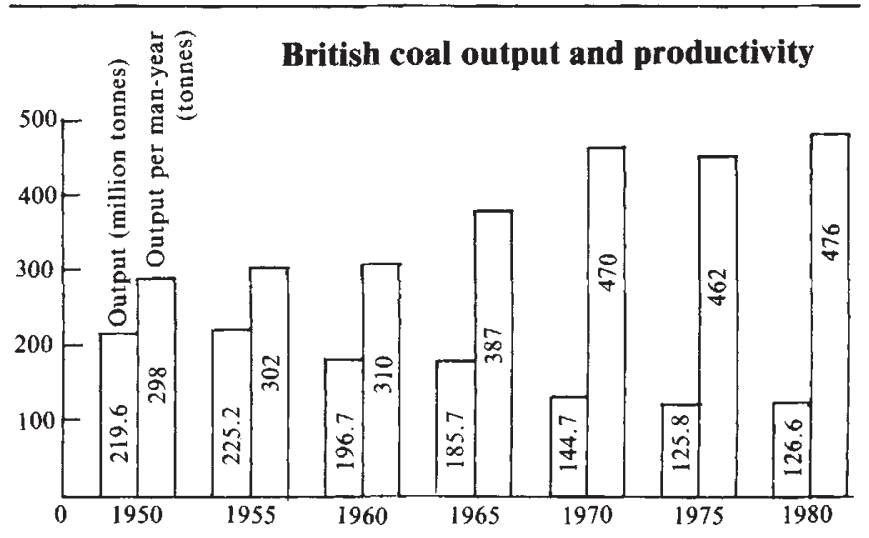

